\title{
THE CONTRIBUTION OF AUSTRALIANS TO MEDICAL KNOWLEDGE*
}

\author{
by
}

\author{
N. R. BARRETT
}

THE history of Australia is short but rich in episode and change. In little more than 150 years a new nation has been born and grown to maturity.

There are several points to make before taking up the story. Every episode must be seen in the light of the exact time at which it happened. Advances in knowledge, during the last 50 years, have exceeded all past time, and the modern generation cannot imagine a world that had no antibiotics. Thus we need a yardstick against which to check events in Australia, and to prevent us taking it for granted that medicine in England was more advanced at any given time. Here is a description by Sir Cuthbert Wallace of the 'new' operating theatres at St. Thomas's Hospital in London-the date is 1890 :

\footnotetext{
The floor was wood, covered with a piece of brown linoleum: the table was of oak, and under the table was a bowl filled with sawdust. There were no aprons or mackintoshes for anyone ... The only washing place was a lead sink with a china basin in it. The instruments were brought up in a wooden case, about one and a half feet square, by the 'surgery' man who looked after them...
}

In this lecture the subject will be divided into two periods. The first covers Australia as a Penal Settlement and Colony, and, during this time, it is not difficult to pick out people and events that made history: the second begins when Australia became a Commonwealth, at the turn of the century, and from then on it is not only impossible to single out events that everybody would agree were important, but in the time available it would be invidious to mention the names of some doctors to the exclusion of others.

I shall look at this subject through the eyes of a critic in a distant country, rather than as an Australian talking about home.

\section{THE EARLY SETTLERS}

The first English doctors to land in Australia brought with them the customs, the beliefs, the knowledge and the practice of medieval England. They arrived at the time when John Hunter was exhorting medical men to discard speculation and to try experiment-at the time in fact when all previous medical practice was about to be examined and discarded. If those who came to Australia had shut themselves off from Europe they would now be a long way behind; but, from the early part of

- This, and the following paper on Medicine in New Zealand by Sir Arthur Porritt, comprises the first section of the Proceedings of the Symposium on The History of Medicine in the Commonwealth, organized by the Faculty of the History of Medicine and Pharmacy and held at the Royal College of Physicians on 23 September 1966. The second section, which includes papers on Africa, Canada, and India, will appear in the January 1968 issue of Medical History. 


\section{N. R. Barrett}

the nineteenth century, some of them came repeatedly to find out what was going on in Europe, and they took the information back with them to Australia.

The settlers had at first little chance to take up the ideas of the age of science that was dawning. They were fully occupied by the problem of how to survive; they lived in a tiny solitary settlement perched precariously on the edge of a continent, and confined by the Pacific Ocean. But the age was not propitious for a medical revolution in England where men's thoughts were centred upon custom, precedent, wars, social upheavals and industrialization. Thus there were circumstances in Australia that favoured the introduction of new ideas and Australians were not slow to use them. Here are some isolated events that testify to this. In 1847 W. R. Pugh used ether anaesthesia in Tasmania-only one year after it was used in the United States. Chloroform was available in Sydney before it was used in Europe, and on 7 February 1872-one year after Lister's Address in Surgery-William Jenkins, who knew Lister, spoke about the subject to the Medical Society of Victoria and W. Gilbee used the carbolic spray a week later. Lister had not come to London at the time.

This history begins in $\mathbf{1 7 7 0}$ when Captain Cook, on his first voyage round the world, discovered and sailed up the east coast of Australia from Cape Howe to Cape York. During this part of his exploration he found Botany Bay which lies just south of Sydney Harbour. He described Botany Bay as a perfect anchorage-but he had not seen Sydney Harbour, which is one of the safest and most commodious in the world.

Captain Cook had two medical officers, William Monkhouse (surgeon) and William Perry (surgeon's mate): these were the first two doctors officially to land on the soil of Australia. But this is not the reason that their names are remembered today; it is because, in the course of this circumnavigation of the world, not a man aboard the Endeavour died from disease contracted at sea. This achievement ranks as one of the greatest in the field of public health: the lessons that had been learnt by Captain Cook were ignored for eighty years.

Australia (or 'New Holland' as it was then called) remained unoccupied by white men for eighteen years after Captain Cook left Botany Bay. In the meantime England had lost the American War of Independence, and, as one result of this, she could not deport convicts to the West. An outlet for this problem had to be found because the prisons and hulks (old ships-of-the-line that were anchored at the Nore and that were used as prisons) were grossly overcrowded. Thus it was that Sir Joseph Banks-who had been with Captain Cook-suggested Botany Bay.

On 18 January 1788 the first British fleet came to anchor in Botany Bay after a journey from England that had lasted eight months. Their orders were to establish and maintain a penal settlement. The fleet consisted of one warship, several supply ships and six transports carrying a total of 759 convicts (men, women and children), four companies of marines, and crews totalling 233 sailors.

The story of this journey, the fate that overtook not only a large number of the convicts but many of those sent to guard them are episodes of cruelty and despair that come to us from the past. One of the few redeeming features was the fact that John White was the surgeon-general to the fleet. He, and his medical assistants became responsible for the health of everybody ashore. At first epidemic diseases 


\section{The Contribution of Australians to Medical Knowledge}

(dysentery, smallpox, and scurvy) were gradually brought under control but, after two years during which no relief ship had arrived, the settlement was close to starvation. Then in June 1790 disaster struck: first the ship Lady Juliana appeared and landed 222 women convicts without food, and later in the same month the notorious second fleet came to anchor, and reported having lost 261 convicts out of a total of 1,000 embarked.

'The slave trade', wrote an officer of the New South Wales Corps who had travelled in the Surprise, 'is merciful to what I have seen in this fleet. Some who had survived the voyage died as the ships came into harbour and were thrown overboard, their dead bodies cast upon the shore were seen laying naked upon the rocks. Several more died in the boats as they were rowing on shore, or on the wharf as they were lifted from the boats. When put ashore many were not able to walk, or stand, or to stir themselves in the least, hence some were led by others. Some creeped upon their hands and knees, and some were carried upon the backs of others ...'

Life in the settlement continued to hang by a thread for many years but John White, who had written a journal of the voyage with the first fleet, managed not only to survive, tend the sick, and supervise the medical administration of the settlement, but he explored the vicinity, and became an observant naturalist. His Journal included his natural history notes. It was published in London in 1790 and it is the first scientific document to come to the Old World from Australia.

Seven years later on 27 August 1797, William Redfern, aged 19, a surgeon's mate in the Royal Navy, was sentenced to death in England for the part he had played in the Mutiny at the Nore. He spent four years in prison in London, and his sentence was then commuted 'to transportation for the term of his natural life'. On 19 January 1802, Redfern, having served part of his sentence as a convict on Norfolk Island and returned thence to Sydney, was pardoned. Eleven years after that he had become the most respected citizen and the best surgeon in the settlement.

In October 1814, Redfern sent a report to Lachlan Macquarie, Governor of New South Wales, concerning the changes that should be made before any more convicts were shipped to Australia. This succinct, and scholarly paper was a contribution to the knowledge of the times and, had his recommendations been put into practice by the Army and by the Royal Navy, not only would his name have ranked with Chadwick and Florence Nightingale as one of the pioneers of public health, but thousands of lives would have been saved. Those who have read Mrs. Woodham-Smith's book about Florence Nightingale will agree that the destruction of the British Army that occurred in the Crimea and at Scutari half a century later-destruction due in large measure to complete neglect of the advice William Redfern had given to Governor Macquarie-could and should have been avoided. The British Army was destroyed because nobody had learnt how to care for large bodies of men in confined spaces: red tape, hopeless deficiences in command and commissariat, the Russian winter, wounds and starvation were all accessories after this fact. Cholera, dysentery, typhus, scurvy and all manner of fevers were the captains of the men of death in the Crimea, as they had been in the prison ships that sailed to Australia.

Sir Edward Ford, in a postgraduate oration (1953) had this comment to make about William Redfern. 


\section{N. R. Barrett}

This proud and rugged figure stands out in added importance as the years pass. He was rich in the attributes that men admire. He was stalwart in adversity, a helper of the weak, a spokesman for the oppressed, a good citizen and a good doctor. He was a man who inspired those who travel the rough road of history.

Before turning to other things we must note that many 'convicts' in the eighteenth century were educated men who made valuable contributions to life in Australia. One, Edward Wakefield, whilst in Newgate prison, worked out a scheme for land distribution and development that revolutionized, in 1830, the agricultural policy of the New South Wales Government. By his endeavours immigrants were made to work on lands allotted to them. 'A colony' he said 'allowed to manage its own affairs, will attract men fit to arrange them'.

\section{ACADEMIC PROGRESS}

I pass to an appraisal of some events that not only altered the pattern of Australian medicine but were of significance to the outside world. The Port Phillip Association in Tasmania organized and planned the first settlement of Victoria along the Yarra River. This happened in 1937 and Melbourne was founded at that time. In this settlement, that rapidly became a large city, the citizens conceived, financed and built their own hospital, and although a similar breakaway from the government-owned hospitals had already occurred in Sydney, the Melbourne Hospital was, from the beginning, associated with the newly-founded university (1853) and as a result of the work of Dr. Anthony Brownless (who was a physician to the hospital and a member of the Council of the University) a medical faculty was started straight away. These events are memorable for two reasons. In 1850 there were only three universities in England (Oxford, Cambridge, Durham) and the study of the classics was regarded as the hallmark of scholarship. Not only did the new University of Melbourne associate itself with the new hospital (albeit loosely at first) but, contrary to the advice of Sir James Paget in London, it decreed that a course of five years-and not four as advised by Paget-would be necessary to secure a medical degree.

At this time in Melbourne and Sydney the first medical societies were founded. But more important is the fact that between 1850 and 1900 more than thirty medical journals came into being. The majority of these lasted only a few years; but one, under various names, sometimes edited in Sydney and sometimes in Melbourne, has survived. The first regular issue of the Australian Medical Journal appeared on 1 August 1846. It ceased publication a year later. In 1856, however, a new journal was started in Melbourne: this ultimately was also called the Australian Medical Journal and it continued until 1914 when it amalgamated with others and became The Medical Journal of Australia. This has appeared regularly ever since. The fact that an important journal could be founded before 1850 (before the British Medical Journal began publication)-and survive-suggests that there was medical news in Australia that was interesting to the outside world.

\section{THE ANATOMISTS}

When the continent of Australia became separated from the land mass of South East Asia, many primitive animals were cut off from comparable contemporary species and left to develop in their own ways. These included the monotremes, the 


\section{The Contribution of Australians to Medical Knowledge}

marsupials (which were virtually unknown elsewhere) the ratite birds (such as the emu and the kiwi) many 'prehistoric' lizards and reptiles (tuatara) and innumerable insects, snakes, plants, fish and corals. Many of these discoveries, which were at first dismissed as travellers' tales, were soon verified, and from that moment there developed in Australia a zeal and enthusiasm for natural history, and subsequently for human anatomy, that had a far reaching effect upon surgical practice.

John White's enthusiasm for exploring the country round Sydney and for collecting plants and animals has already been mentioned. In the course of these journeys he shot or captured a number of strange animals, amongst them some kangaroos. It is probable that Captain Cook was the first Englishman to see a marsupial, but he did not describe it in his journal. White discovered that kangaroos carried their immature young in abdominal pouches and he sent a number of embryos to John Hunter in London. Some of these can still be seen today: they are a part of the Hunterian Collection at the Royal College of Surgeons.

In 1797 Colonel David Collins wrote from New South Wales to a friend in London concerning a peculiar animal he had seen whilst exploring the Hawkesbury River. It had, he said, webbed feet and a beaverlike tail; it was covered with fur; 'but the most extraordinary circumstances . . . was its having, instead of the mouth of an animal, the upper and lower mandibles of a duck . . . its webbed feet enabled it to swim, whilst on shore its long sharp claws were employed in burrowing.' A few years later the Governor of New South Wales (James Hunter) sent two specimens of platypus to the British Museum, and these were dissected by Everard Home who found that they were primitive mammals: so primitive that they had originated more than $\mathbf{5 0}$ million years before man. He communicated his opinions to the Royal Society and these learned gentlemen were, at first, unable to believe their ears. Not the least of the improbabilities was that the duck-billed platypus laid eggs and suckled its young.

The question as to whether the platypus really laid eggs was hotly disputed as a zoological improbability, and the matter was not settled until 1884 when Caldwell (a zoologist from Cambridge) went to Australia for the express purpose of clearing the matter up. He found two eggs after much searching. He also confirmed that the spiny-ant-eater was a monotreme.

The first distinguished Australian naturalist was George Bennett whose life spans the nineteenth century (1804-1893). His first important discovery was a living specimen of pearly nautilus which he found in the New Hebrides. This extraordinary cephaloped had been vaguely described by Aristotle in his book The History of Animals; but nobody knew much about it. Bennett not only observed the habits of the animal but he made his own dissections, for which he was awarded the Gold Medal of the Royal College of Surgeons. He was the third recipient of this valued award. The interest in the pearly nautilus centred not so much upon the beauty of its shell, but upon the complexity of its anatomy: it was at one time regarded as a possible bridge between the vertebrate and invertebrate species. Bennett also sent specimens of nautilus to London, and Richard Owen wrote his famous Memoire upon the subject in 1832. Bennett continued his activities with such enthusiasm that there is a record in the College of Surgeons that 510 zoological specimens of all kinds were awaiting dissection by Owen. The latter wrote 'From their rarity and the good state of their 


\section{N. R. Barrett}

preservation ... these specimens are intrinsically of great value: but this is much increased by the copious and accurate observations on the locality, temperature, time of day and other circumstances connected with their capture'.

Bennett established a tradition of careful anatomical research that was emulated by an increasing number of brilliant men, many of whom were Australians; others came to Australia because they could not afford to miss the experience.

The Australian human and comparative anatomists included that eccentric and famous teacher, Professor Archibald Watson, Sir Thomas Stuart, Sir Alexander MacCormick, Sir Edward Stirling, Sir James Barrett, Sir Grafton Elliot Smith and many others. At the turn of the century these men had made reputations not only for the quality of their contributions, but for the excellence of their teaching. Amongst those who came to work in Australia was F. Wood-Jones who was, possibly, the greatest anatomist of them all. His enquiries ranged over a wide variety of subjects and whilst he was in Australia he studied the corals in much detail.

\section{A LONG SEA VOYAGE}

Between 1830 and 1900 many medical papers were written by eminent British physicians and phthisiologists stating that a voyage to Australia in a square-rigger would cure pulmonary tuberculosis-and some mental disorders-more certainly than any other treatment available at the time.

Several things combined to lend colour to this claim. In 1750 Dr. Richard Russell had put forward a theory that sea-water was beneficial for all gland diseases, and he established a coastal health centre at Brighton which was patronized by the Prince of Wales. Patients were required to drink sea-water and bathe regularly. Between 1756 and 1771 three English editions, and a French translation, of Gilchrist's book, The Therapeutic Value of Sea-Voyages were printed. And before 1800 regular sea voyages for consumptives were made between England and Lisbon (see Journal of a Voyage to Lisbon by Henry Fielding, 1775). Then in the early part of the nineteenth century the great Laënnec stated that sea air-because it contained iodine emanating from seaweed -was curative in some patients suffering from consumption.

In addition to these beliefs there was another that was equally strange, namely that Australians were immune to phthisis; and that all who landed there would be cured. So prevalent was this hope that whole families emigrated and several eminent physicians took the cure themselves. In fact the position was sadly different for there were 10,000 deaths from pulmonary tuberculosis in Victoria in the third decade of the Colony's existence (1861-71).

Tuberculosis, which was introduced into Australia with many other noxious diseases of white men, reached its peak of severity during the gold rush in Victoria in the 1850 s. Since then the incidence has been declining in a way comparable to that in other civilized communities. Australian tuberculosis was no different to tuberculosis elsewhere, and Australians were quick to point out and to resent the cult of the 'long sea voyage'. But the craze caught on and was exploited by shipowners: in fact it continued to be profitable to them at least until the first world war.

To meet this considerable passenger trade, a number of sailing ships-both large and small-were hastily modified and pressed into service. Of these the most renowned 


\section{The Contribution of Australians to Medical Knowledge}

was one of the finest of the tea-clippers, the Sobraon, which was diverted to the passenger trade; and even after the introduction of fast steamships Basil Lubbock wrote in 1927 'Doctors still realize the value of a sea-voyage for certain types of patient: but in spite of the comforts and luxuries of steam, it can never compare with sail in restoring health', and in this statement there is more than a measure of truth. The Sobraon was a ship of 2131 tons; 300 feet overall, spreading two acres of canvas. Her average time for the passage to Melbourne was 70-90 days-a veritable flyer. On these voyages she carried 84 first-class patients and 50 in the second class: there were, for their comfort, 3 bullocks, 3 milking cows, 90 sheep, 50 large hogs, many sucking pigs and 400 head of poultry aboard.

Excursions into the ridiculous, such as these, should make doctors today wonder as to the sense of some of the treatments they prescribe empirically. It is entirely possible that a sea voyage in a beautiful sailing ship would do anybody good: but very few ships were like the Sobraon. Indeed, we read accounts of consumptives huddled together in small, ill-ventilated cabins and it was usual for these ships, having picked up their passengers at Tilbury, to call at Falmouth to land those who were about to die.

\section{WOMEN}

On 1 December 1867 the Dunbar Castle anchored off Sydney Harbour and was towed to moorings the next day. Mr. Henry Parkes (later Sir Henry), the Colonial Secretary to the New South Wales Government, came aboard to welcome Miss Lucy Osburn and a party of five young ladies.

Lucy Osburn was one of the first nurses to be trained at St. Thomas's Hospital under the aegis of Florence Nightingale. At that time there were very few trained nurses anywhere in the world: patients were cared for by men and women of the lowest social status. Cruelty, drunkenness, ignorance, dirt and infection regulated the lives of many who were admitted to hospitals.

Miss Nightingale was not only determined to end such things but she knew how to do it. Educated young ladies were to be trained as nurses: it was demanded of them that they be totally devoted to the care of the sick, and that they must accomplish everything to that end. Her second step was to send small groups of trained nurses, under the absolute charge of one of their number, to work in some of the most notoriously bad hospitals in England. They were to prove that nursing was a career for ladies and that they could do the work. The unbelievable story of Miss Agnes Elizabeth Jones, who went with a group to the Workhouse Infirmary in Liverpool and who died of typhus, convinced everybody from the chief constable to the Lord Lieutenant that these nurses had let new light into a dark corner. But at this very moment the senior surgeon at St. Thomas's was writing to the Treasurer objecting to Lady Jane Shaw Stewart being enrolled as a probationer.

In 1866 Henry Parkes, at the instigation of the New South Wales Government, wrote to Florence Nightingale asking her advice about nursing in the Colony and the possibility of founding a school for nurses at Sydney Hospital. Miss Nightingale straightway agreed to send Miss Lucy Osburn with a party of five trained nurses. Lucy Osburn was not 30 years of age; she was the second of Florence Nightingale's 
missionaries, and the fact that she-or any of the others-was prepared to travel to Australia for such a purpose is a vivid example of the power that Miss Nightingale had over the nurses trained in her name.

Lucy Osburn and her nurses went to work in Sydney Hospital, and from the first she was almost overwhelmed with difficulties, misunderstandings and loneliness. Here is a part of Cope's description of the hospital.

In 1868 Sydney was a city of 100,000 people, and the hospital or infirmary had 160 beds housed in an old and inconvenient building. The nursing care of the male patients was entrusted to "ward masters' who locked the wards at night ... The female patients were looked after by unskilled and untrained women of the Sarah Gamp type. The sanitary provisions in the wards were sadly deficient. In one part of the hospital there was not a drop of water for the upstairs wards ... whilst in another there was no W.C., no sink, no tap ... all the slops were emptied into a pail which was carried through the whole length of the female surgical ward and along the verandah to a W.C. containing one seat for fifty patients.

In spite of descriptions such as these, Australian hospitals, of a comparable period in time, were not as bad as the Poor Law Institutions in England. They had the benefits of open spaces and of not being smothered and contaminated by industrial developments. The criticisms that could be levelled against them were not in the field of nursing; they were that at least one quarter of all patients, in the 1860 s, died in the hospitals.

Lucy Osburn and her nurses were not saints or ministering angels; indeed the success of their enterprise was almost defeated by dissent, scandals and petty criticisms. Four of her nurses left the hospital when their three-year contracts were up. But Lucy was made of stern stuff: she possessed that indomitable quality-belief in herself and her mission-that carried her through her tribulations.

At the end of three years she was almost at the end of her tether; alone and dispirited; and at this moment the Government of New South Wales set up a commission, under Judge Windeyer, to enquire into the allegations of incompetence that had been brought against her. The commission reported that every department of the hospital, except the nursing staff, was defective, and Lucy Osburn was vindicated. Fourteen years later when she retired to England she had founded her own nursing school and this has flourished ever since. We, who are accustomed to the high standards of modern nursing, find it difficult to understand the change that young women like Lucy Osburn accomplished. They totally altered current opinion as to their profession; they demonstrated the difference between menial servants and educated people; and they revolutionized the appearance and safety of hospitals.*

After the success of the Nightingale nurses at Sydney the Tasmanian Government brought out nurses from St. Thomas's to reorganize the hospitals in Hobart and Launceston: the Alfred Hospital was placed under Miss Turriff as matron: the Melbourne Hospital took Miss Rathie from the Edinburgh Royal Infirmary and Brisbane took a matron from Charing Cross Hospital. Two nurses from the London Hospital went to the General Hospital in Adelaide.

But nurses were not the only women to wage the long battle, against hardened prejudice, to secure professional status. In 1881 the universities of Sydney and Mel-

\footnotetext{
- In her will (which amounted to about 1700 ) Lucy Osburn mentions Judge Windeyer with gratitude: she left him $£ 100$.
} 


\section{The Contribution of Australians to Medical Knowledge}

bourne timidly agreed to admit women medical students: the British Government had passed an act to remove restrictions on the granting of medical qualifications, on the grounds of sex, only five years earlier. No sooner had this been done than a number of women became doctors. Not the least of their achievements was the founding in Australia of two hospitals staffed entirely by women. The Queen Victoria Hospital for Women and Children (Melbourne) was opened in 1896. This is now one of the largest of its kind in the Commonwealth: in the early 1950s it had a daily average of 335 in-patients and 100 cots, with an honorary medical staff of 51 women specialists and 20 residents. The other successful endeavour was the Rachel Foster Hospital for Women and Children in the industrial suburb of Redfern in Sydney.

Thus Australian women, and women in Australia, have achieved much, and by so doing they have set an example for others to follow. In recent years Australian nurses have served in New Guinea, Malaysia, Singapore and other countries involved in S.E.A.T.O. and the Colombo Plan; and many served overseas during the two world wars.

\section{RESEARCH}

We have now reached the turn of the century, and by this time Australian medicine was ready to compete in the world at large: disadvantages of distance had been eliminated and men were available to meet the challenge. But before passing into this new and exciting era let us read some words written by C. H. Kellaway (himself a pioneer of Australian research) 'In a young country there is little opportunity for development of scientific research. The pioneers are fully occupied in the struggle for existence, and many years must elapse before the conditions of life afford to suitable persons the necessary leisure and detachment to set about the business of adding to the world's store of knowledge ...'

The first research project of world importance was carried through in Queensland by Joseph Bancroft in 1876: he discovered the parent filarial parasite that now bears his name. He also studied the modes of transmission of many insect-borne fevers. The first classic paper on hydatid disease was written in 1884 by J. D. Thomas.

The man who had the vision to see that Australian doctors must have their own research institutes was H. B. Allen (Professor of Anatomy and Physiology at the University of Melbourne) after a visit to Europe in 1890, and knowing Koch and Pasteur, he set out a detailed plan for an Institute of Preventive Medicine in Melbourne and submitted this to Parliament. But neither Parliament nor the University was ready, and it was not until 1910 (20 years later) that the Hospital decided to include facilities for clinical pathological research. Before these plans could be initiated the first world war was declared and progress was interrupted. Organized medical research began in Australia during that war.

Since 1920 the Commonwealth Government has shown an increasing interest: government research institutes have been set up in Canberra and the National Health and Medical Research Council was formed to examine projects and allocate funds. The cost of medical research in Australia has been rising. In recent years the amount contributed from the national purse has averaged about $0.035 \%$ of the total income (the comparable figures for the United Kingdom and the U.S.A. are $0.08 \%$ and $0.19 \%$ ) but these have not been the only contributions. The sources from which funds are now 


\section{N. R. Barrett}

available are the Commonwealth Government (through the John Curtin School of Medical Research, the National Health and Medical Research Council); the state governments; the state universities; the hospital and medical research institutes (i.e. the Baker Institute in Melbourne, Walter and Eliza Hall Institute also in Melbourne, the Kanematsu Institute in Sydney and many others); certain research grants from industry; and private funds and bequests.

Almost all the research is carried out in, or by, universities, large hospitals, government health departments or medical research institutes, and these have attracted some of the best scientists available. Australians realize that the health and happiness of any community is greatly affected by the quality of the national medical services. To achieve this end, good doctors, taught by good teachers, must be available, and experience shows that, nowadays, the best teachers are men who are themselves concerned with research. Australian doctors have won Nobel Prizes.

It will not be possible to describe the projects that have already borne fruit, nor to give a list of the men engaged in research and teaching; but here are a few of the contributions that have come from Australia during the last 25 years. They have been in many fields, and notably virology, immunology, microbiology, neuro-physiology, the pathology of arterial disease, the investigation of insect-borne fevers, and the development of penicillin. In addition it has been proved that certain congenital deformities (notably those that affect the heart) can be caused by maternal rubella occurring during the first three months of intra-uterine life.

In recent times Englishmen have seen with regret, but without surprise, that young and progressive Australians are more in sympathy with the American practice of medicine than with the British. The importance of research, as a part of the education of every doctor who aspires to higher things, was accepted and implemented a long time ago in the United States. In England the emphasis is still on patient care, and research is reserved for a minority. Young Australians, having to choose between these two paths have, understandably, accepted the generous, elaborate and expensive facilities that the large American clinics offer them. In this direction they have set their sights, and although educational links still exist with the Royal Colleges in the United Kingdom, these are not enough to influence Australian thought today. It may be presumptuous to do so but I predict that in time to come the Americans and Australians will turn again to clinical medicine and the English will feel their way towards more research. Modern methods, excellent though they are, often produce men who are not primarily interested in treating patients.

\section{THE OUTBACK}

The crossing of the Blue Mountain Barrier by Blaxland, by Lawson and by Wentworth in 1813, the explorations that followed and revealed the endless lands to the West, not only opened up 'the outback' - or the 'Dead Heart' of Australia-but immediately brought urgent and continuing medical challenges.

These desert lands, fringed with rich pastures, are of infinite size ( 2 million square miles): they are dried by a baking sun; a place where rain seldom falls, where there are no trees and hardly a sign of life; they seemed to the early explorers to be of no useful purpose. But it was not long before the Murray, the Darling and the Murrumbigee 


\section{The Contribution of Australians to Medical Knowledge}

Rivers were discovered, and men learned that fine sheep and cattle could be raised in many places. This development changed the face of the colony: wool, instead of rum, became the currency in Sydney and organized farming replaced the convicts' settlements. As the settlers, stockmen and farmers pushed their ways into new lands the immediate problems of how to survive, of how to live in such heat, how to overcome the feeling of absolute loneliness that engulfed families separated from each other by hundreds of miles of impassable country; and of how to get water; these problems became paramount and medical men were soon involved.

The future of this hinterland will depend upon an inexhaustable supply of clean water: many believe that in the quantities that will be needed (for much of the land is fertile if irrigated) this water must ultimately come from the sea; but already great progress has been made in diverting rivers, building conservation dams, boring artesian wells and even in tapping clouds.

Meanwhile doctors have made contributions, many of which are of world interest and application. These include techniques of desert survival; the effects of heat stroke, thirst and desiccation; the management and the pathology of snake-bite and of a variety of parasitical diseases (such as hydatid disease, filariasis and many insectborne fevers); the control of pests, cattle and sheep diseases; and, in the fields of comparative zoology and of anthropology new ideas have been opened by the study of the aboriginal peoples.

Whilst all these things have been happening a special medical event took place in the outback. This not only captured the romantic admiration of the world but it expanded and developed into an enterprise that has revolutionized life in the 'dead heart' of Australia.

The Royal Flying Doctor Service of Australia was conceived, developed against almost impossible obstacles, and brought to fruition by the Rev. John Flynn (18801951). Here is his epitaph:-

His vision encompassed the Continent

He established the Australian Inland Mission and founded the Flying Doctor Service

He brought to lonely places a spiritual ministry and spread a mantle of safety over them by Medicine, Aviation and Radio.

Today the Royal Flying Doctor Service spans practically the whole of Australia. Every outlying station has its own radio transmitter/receiver apparatus and prompt medical care, with base hospital facilities, is available. Aircraft specially suited to the purpose have been brought into service, and the organization operates from about fifteen bases. At certain times in the day the radio service is thrown open for people living hundreds of miles away from their nearest neighbours to talk together; a full course of teaching, for children of all ages, is available; and medicines, emergency stores, and equipment can be flown in at short notice.

This service has not only been a stimulus to the medical men who operate it, but it has produced the possibilities of a reasonable life in the outback. Sir Robert Menzies said about it, 'wherever I have gone in the world I have found that the Flying Doctor Service of Australia is known and is vastly admired'.

HOSPITAL ORGANIZATION AND NATIONAL HEALTH

The visit that Dr. William Mayo made to Australia in 1924 is worthy of comment. 


\section{N. R. Barrett}

Having seen the surgical work in all the large centres he described it as second to none; but he also said, 'All the wonderful facilities of these splendid institutions are reserved for poor men and tramps and the rest of the community is taxed to pay for them.'

By this he meant that, following the English voluntary hospital type of practice, the Australians had evolved a fine service for the poor, a good service for those who could pay private nursing-home fees, and a bad service for the large middle income group. It was also evident that there was still indecision as to the best interconnection between teaching hospitals and universities, and the status of 'consultants' or 'voluntary' teaching staff. These doubts and difficulties have now been resolved and, although there has been a swing away from the British Voluntary Hospital, and from the state medical service as we know it, towards the American community hospital, the Australians, through their Royal Colleges, and by their family ties, have kept some of the things that are British. They have evolved their own brands of state and university hospital, and of public health service.

A special national health service is in being. In this the state accepts responsibility for certain services and drugs: the remainder is covered by insurance schemes that are supervised by the state. This scheme seems to suit local conditions and works equitably.

\section{AUSTRALIANS}

Many generous and warm tributes have been paid by doctors all over the world to Australians, and especially by enthusiastic admirers such as the late Sir Gordon Gordon-Taylor (1947). These have underlined the many qualities of strength that fit a people to carry through their destinies.

Since the earliest colonial days doctors in Australia have been held in high repute by the community. This happened not only because there was no built-in aristocracy to hinder them; but because they were, in fact, amongst the best educated of the people. Moreover, they played decisive parts in exploration, agriculture, administration, and science. They saved the early settlers and the convicts from extinction. They helped with the layout of new cities and all matter pertaining to public health. They made their contribution to the settlement and use of the outback, and now they are competing in the world of modern medical science.

One hundred years onward there may still be places in the remote parts of this continent where medical science is not available. Water will dictate the future; and there are those alive today who may live to see an explosion in population comparable to that of China. Meanwhile, having looked superficially at what has already been accomplished in the short span of 150 years I say with humility and admirationgood luck in the future.

\section{BIBLIOGRAPHY}

Australia. Flying Doctor 1955, Reference paper No. 20 Informatiơn Bureau, Canberra, Thomas Urquhart, Melbourne.

Chambers Encyclopaedia: Australia.

Cleland, J. B., 'Medical names in Australian geographical nomenclature', Med. J. Aust., $1934,1,549$.

Cleland, J. B., ‘Australian convict doctors', Med. J. Aust., 1938, 31, 1439. 


\section{The Contribution of Australians to Medical Knowledge}

CoPe, Sir Zachary, Six Disciples of Florence Nightingale, London, Pitman Medical Publishing Co., 1961.

Crowther, W. E. L. H., 'The introduction of surgical anaesthesia to Van Diemen's Land', Med. J. Aust., 1947, 2, 561'

FORD, E., The Life and Work of William Redfern, Annual post-graduate oration University of Sydney 1953, Australian Publishing Co.

FORD, E., 'Medical practice in early Sydney with special reference to the work and influence of John White, William Redfern and William Bland', Med. J. Aust., 1955, ii, 41-54.

ForD, E., 'The life and influence of Joseph Bancroft', Med. J. Aust., 1961, 48 (1), 153-70.

FosTeR, F. M. C., 'Mrs. Howlett and Dr. Jenkins, Listerism and early midwifery practice in Australia', Med. J. Aust., 1965, 26, 1047.

GaNDEVIA, B., 'Early days of anaesthesia (c. 1847)', Med. J. Aust., 1954, i, 385.

Gandevia, B., An Annotated Bibliography of the History of Medicine in Australia, London, British Medical Association, 1957.

Gandevia, B., 'The pattern of Australian medical history', Proc. $R$. Soc. Med., 1957, 50, 591.

GandeviA, B., and Tovell, A., 'Early Australian medical convicts', Med. J. Aust., 1962, 49, 756.

Gordon-Taylor, SIR Gordon, 'The debt of surgical science to Australasia' (The George Adlington Syme Oration), Aust. N.Z. J. Surg., 1947, 17, 75.

HARLEY, J. F., Mantle of Safety, London, Robert Hale, 1963.

INGLIs, K. S., Hospital and Community: a History of the Royal Melbourne Hospital, Melbourne University Press, 1958.

KвоGH, E. Y., 'Fifty years of medical research in Australia', Med. J. Aust., 1951, i, 1.

Lubbock, Basil, Sail, London, The Blue Peter Publishing Co., 1927.

MACKERRAS, I. M., 'Australia's contribution to our knowledge of insect-borne disease', Med. J. Aust., 1948, i, $157-67$.

MeYers, E. S., 'Jackson Lecture', Med. J. Aust., 1946. ii, 505.

OWEN, R., Memoir on the Pearly Nautilus, London, Royal College of Surgeons of England, 1832.

Progress of the Australian Territories, 1952-1962, London, Commonwealth Government Printers.

REDFERN, WILLIAM, Report to his Excellency Governor Macquarie 1814, Historical Records of Australia Series I, vol. 8, 1916, pp. 275-93.

Report of the National Health and Medical Research Council 59th Session.

RIENTI, REX, 'Biographical Introduction' to John White's Journal, republished 1962.

Russell, K. F., 'The Royal Melbourne Hospital and its early surgeons 1841-1900', Royal Melbourne Hospital Clinical Reports, August 1948. Centenary Volume.

Russell, K. F., 'The foundation of the medical school of the University of Melbourne', Med. J. Aust., 1962, p. 228.

Stokes, A. F., 'One hundred years of medical history in South Australia', Med. J. Aust., 1937, p. 161.

Susman, M. P., 'Lucy Osburn and her five Nightingale nurses', Med. J. Aust., 1965, i, 633.

The Australian Encyclopaedia: Medical Research, Medical Profession, Surgical Profession.

ThOMAs, B., and GANDEVIA, B., Dr. Francis Workman, Emigrant, and the history of taking the cure for consumption in the Australian Colonies (Bibliography of 75 papers).

Voyage de Lapérouse autour du monde pendant lés années 1785-1788, Les Libraires Associés, 1965.

Wallace, C., '1886 and some years after', St. Thom. Hosp. Gaz., 1937 36, 469.

Watson, J. K., The History of the Sydney Hospital from 1811-1911, Sydney Government Printer, 1911.

Whrte, JoHn, Journal of a voyage to New South Wales, originally published in 1790, Angus and Robertson, 1962. (This book contains an excellent bibliography and many beautiful natural history drawings).

Woodham-Smrth, C., Florence Nightingale, London, Constable, 1950. 